Oscar Ulf Petring MD, Benny Adelhøj MD, Merete Ibsen, Henrik Enghusen Poulsen MD

\section{Effect of chlorprom- azine on drug absorption and gastric emptying in man}

mazine on drug absorption and liquid phase gastric emptying in man using paracetamol absorption as an index of gastric emptying rate. Simultaneous measurements of paracetamol absorption and gastric emptying have confirmed measurements of the rate of paracetamol administered orally as a dependable expression of gastric emptying. ${ }^{6,7}$

\section{Methods}

Informed consent was obtained from each subject, and the experimental study was approved by the local ethics committee. We studied seven healthy volunteers, three women and four men (aged 21-39 years, body weight $45-85 \mathrm{~kg}$ ), on two occasions in random order, with an interval of at least two weeks. On each occasion, after an overnight fast, the subjects laid at rest in bed and were given, in a double-blind fastion, chlorpromazine $25 \mathrm{mg}$ or 0.9 per cent $\mathrm{NaCl}$ (saline) IV. All patients received a slow intravenous infusion of 1.0 litre normal saline during the study. Following the administration of chlorpromazine all volunteers developed typical behavioural effects as drowsiness and diminished response to a varicty of stimuli and were thus aware of the treatment they had received.

On both occasions the subjects ingested $20 \mathrm{mg} \cdot \mathrm{kg}^{-1}$ paracetamol with $200 \mathrm{ml}$ of water $30 \mathrm{~min}$ after chlorpromazine or placebo injection. Venous blood samples were taken from an indwelling cannula before and 10,20,30, $40,50,60,75,90,105$ and 120 min after paracetamol administration.

The maximum plasma concentration for a person was designated $\mathrm{C}_{\max }$, and the corresponding sampling time $\mathbf{T}_{\text {max }}$. The area under the plasma concentration-time curve AUC was calculated by the trapezoidal rule without extrapolation to infinity.

Serum was separated and stored at $-20^{\circ} \mathrm{C}$ until measurement of serum paracetamol concentration by high performance liquid chromatography was performed. ${ }^{8}$ Samples were analyzed in duplicate and in random order. The coefficient of variation of the assay was three per cent, and the recovery of paracetamol in blank plasma $97 \pm 3$ per cent (s.d.). 


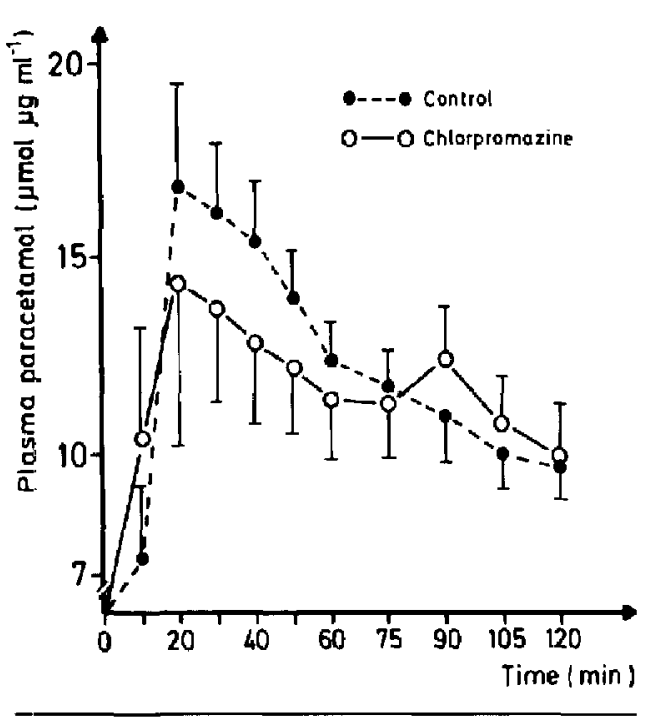

FIGURE Mean plasma paracetamol concentrations ( \pm SEM) at each sampling time with and without chlorpromazine administration.

\section{Statistics}

Data were compared using Student's t test for paired data. $P$ values $<0.05$ were considered statistically significant.

\section{Results}

Mean plasma paracetamol concentrations at each sampling time are given in the Figure. None of the observed differences, i.e., $\mathrm{C}_{\max }, \mathrm{T}_{\max }, \mathrm{AUC}$ attained statistica] significance $(p>0.10)$.

The individual values of $\mathrm{C}_{\max }, \mathrm{T}_{\max }$ and $\mathrm{AUC}$ are given in the Table. At no sampling time did the mean paracetamol concentration after chlorpromazine administration differ significantly from the mean concentration after placebo $(\mathrm{p}>0.05)$.

After placebo administration the mean $( \pm S E M) C_{\max }$ was $18.5 \pm 2.1 \mu \mathrm{g} \cdot \mathrm{ml}^{-1}(\mathrm{n}=7)$, the mean $\mathrm{T}_{\max }$ was $35.7 \pm 5.3 \mathrm{~min}$, and the mean AUC was $1403 \pm$ $122 \mu \mathrm{g} \cdot \min \cdot \mathrm{ml}^{-1}$. After chlorpromazine the mean $\mathrm{C}_{\text {max }}$ was $18.6 \pm 3.2 \mu \mathrm{g} \cdot \mathrm{ml}^{-1}$, the mean $T_{\max }$ was $35.0 \pm 9.9$ min and the mean AUC was $1363 \pm 170 \mu \mathrm{g} \cdot \mathrm{min} \cdot \mathrm{ml}^{-1}$ $(p>0.05)$.

Gastric emptying was delayed slightly in one subject and accelerated slightly in two subjects, as compared with the differcnces from the two occasions in the other persons. The differences in $\mathrm{C}_{\max }, \mathrm{T}_{\max }$, and AUC were not statistically significant; data and the results of paired $t$ test analysis are given in the Table. The mean differences and the 95 per cent confidence limits were: $C_{\max }$ :
$-0.06 \mu \mathrm{g} \cdot \mathrm{ml}^{-1}(95$ per cent: -7.8 to 7.9$), \mathrm{T}_{\max }: 0.7 \mathrm{~min}$ (95 per cent: -14 to 16); and AUC: $40 \mu \mathrm{g} \cdot \min \cdot \mathrm{ml}^{-1}(95$ per cent: -346 to 426 ).

\section{Discussion}

In the present study paracetamol absorption was used as an index of gastric emptying. This method has been demonstrated to correlate well with other methods used to estimate gastric emptying of liquids. ${ }^{7}$ The relationship between gastric emptying of solids and paracetamol absorption is unknown. Liquid and solid phase empty at different rates and pattern, and patients may demonstrate normal emptying of liquid while actually retaining the solids. However, in normal persons there is a correlation between the rates of emptying of solids and liquids. ${ }^{9}$

This study demonstrates that paracetamol absorption was not significantly changed by a single, modest dose of chlorpromazine $25 \mathrm{mg}$ IV to seven healthy volunteers receiving paracetamol $20 \mathrm{mg} \cdot \mathrm{kg}^{-1}$ dissolved in $200 \mathrm{ml}$ of water.

The patterns of gastric emptying were similar in the seven subjects. However, gastric emptying was delayed slightly in one subject (\#3) and accelerated slightly in two others (\# 2 and \# 6) after chlorpromazine IV. This may reflect small, insignificant individual variations in the rate of gastric emptying produced by chlorpromazine, as the changes were independent of sex and body weight of the volunteers.

The 95 per cent confidence limits, i.e., -25 min to 38 min, are not broad enough to reflect clinically significant changes. The magnitude of changes that are clinically important are hours, as exemplified by an earlier study of buprenorphine, which prolongs gastric emptying. ${ }^{10}$ Whether chlorptomazine can change gastric emptying in such a situation is unknown.

The results suggest furthermore that the mechanism by which chlorpromazine exerts its antiemetic effect is not mediated via gastric emptying, but only through the effect on the chemoreceptor trigger zone. Chlorpromazine should, therefore, be less suitable in treatment of emesis caused by gastric retention. However, to confirm this hypothesis a study population with emetic patients must be investigated.

Chlorpromazine's lack of effect on gastric emptying of fluids is the more important finding and has clinical implications. The result suggests, for example, that chlorpromazine given before anaesthesia should not impair absurption of concomitantly administered oral medication

As several antipsychotic agents chlorpromazine seems to act as analgesic, either alone or in combination with traditional analgesies. Shimm et al. have shown that patients given antipsychotic treatment could reduce or 
TABLE The individual values of the peak serum paracetamol concentration $\mathrm{C}_{\max }\left[\mathrm{mg} \cdot \mathrm{m}^{-1}\right)$, the time from administration of paracetamol to its peak

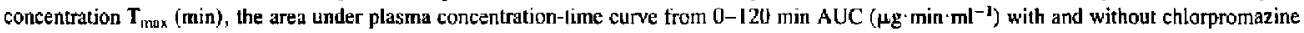
(chlorp.) administration, the differences in $C_{\text {max }}, T_{\text {max }}, A U C$ and $P$ values

\begin{tabular}{|c|c|c|c|c|c|c|c|c|c|}
\hline Subject & $\begin{array}{l}C_{\text {nax }} \\
\text { Saline }\end{array}$ & $\begin{array}{l}C_{\operatorname{mux}} \\
\text { Chlorp. }\end{array}$ & $\begin{array}{l}\text { Diff. } \\
C_{\max }\end{array}$ & $\begin{array}{l}T_{\max } \\
\text { Saline }\end{array}$ & $\begin{array}{l}T_{\max } \\
\text { Chlorp. }\end{array}$ & $\begin{array}{l}\text { Diff. } \\
T_{\text {mar }}\end{array}$ & $\begin{array}{l}\text { AUC } \\
\text { Saline }\end{array}$ & $\begin{array}{l}\text { Al'C } \\
\text { Chlorp. }\end{array}$ & $\begin{array}{l}\text { Diff. } \\
A U C\end{array}$ \\
\hline 1 & 20.54 & 9.59 & 10.95 & 20 & 20 & 0 & 1450 & 804 & 646 \\
\hline 2 & 22.49 & 35.25 & -12.76 & 30 & 20 & 10 & 1513 & 2103 & -590 \\
\hline 3 & 15.39 & 16.80 & -1.41 & 60 & 90 & -30 & 1360 & 1072 & 288 \\
\hline 4 & 28.33 & 17.31 & 11.02 & 20 & 20 & 0 & 1956 & 1590 & 366 \\
\hline 5 & 11.99 & 12.86 & -0.87 & 40 & 40 & 0 & 899 & 938 & -39 \\
\hline 6 & 16.04 & 22.38 & -6.34 & 40 & 15 & 25 & 1182 & 1516 & -334 \\
\hline 7 & 14.89 & 15.87 & -0.98 & 40 & 40 & 0 & 1458 & 1514 & -56 \\
\hline Mean & 18.5 & 18.6 & -0.06 & 36 & 35 & 0.7 & 1403 & 1362 & 40 \\
\hline SEM & 2.1 & 3.2 & 3.37 & 5.3 & 9.9 & 6.2 & 122 & 171 & $16 \mathrm{~L}$ \\
\hline P value & & & 0.99 & & & 0.91 & & & 0.81 \\
\hline
\end{tabular}

even eliminate their narcotic treatment." Chlorpromazine, however, is not widely used by anaesthetists as a premedicant, and therefore further studies are needed to show its usefulness to reduce the use of opioids, the major cause of delayed gastric emptying in the perioperative period. $^{2,12}$

Many of the undesirable side effects of chlorpromazine may be related to high plasma concentration levels seen after multiple, high-dose administration. These levels may not be necessary to provide adequate preoperative sedation as all subjects in this study showed behavioural effects as drowsiness and diminished response to a variety of stimuli after only a single dose of $25 \mathrm{mg} \mathrm{IV.}$

Consequently, as judged from paracetamol absorption, chlorpromazine in relatively modest antiemetic and sedative doses does not alter drug absorption and gastric emptying in healthy volunteers. Nevertheless, higher and more prolonged doses of the drug have marked anticholin ergic effects that possibly could have produced a different effect on gastric emptying. ${ }^{3,5}$

\section{References}

1 Clarke RSJ. Nausea and vomiting. Br J Anaesth 1984; 56 : 19-27.

2 Nimmo WS. Effect of anaesthesia on gastric motility and emptying in man. Br J Anaesth 1984; 56: 29-36

3 Baldessarini RJ. Drugs and the treatment of psychiatric disorders. In: Goodman LS, Gilman A. The phamacological basis of therapeutics. The MacMillan Company, 7 th ed, New York $1985 ; 387-412$

4 Seiget $L$, Longo $D L$. The control of chemotherapy induced emesis. Ann Intern Med 1981; 95: 359-9.

5 Rentzhog L, Wikström S. Pharmacological effects on gastric emptying following laparotomy in the rat. Acta Chir Scand $1975 ; 141 ; 649-53$.
6 Heading RC, Nimmo J, Prescort $L F$, Tothill $P$. The dependence of paracetamol absorption on the rate of gastric emptying. Br J Pharmacol 1973; 47: 415-21.

7 Clements JA, Heading RC, Nimmo WS, Prescott $L F$. Kinetics of acetominophen absorption and gastric emplying in man. Clin Pharmacol Ther 1978; 24: 420-32.

8 Knox $J$. Surand J. Determination of paracetamol and its metabolites in urine by high performance liquid chromatography using reversed-phase bonded supports. J Chromatogr 1977; 142: 651-70.

9 Heading RC, Tothill P, McLoughlin GP, Shearman D.C. Gastric emptying rate measurement in man; a double isotope scanning technique for simultaneous study of liquid and solid components of a meal. Gastroenterolugy 1976; 71: 45-50.

10 Adelh $\phi j$ B, Petring OU, Ibsen M, Brynmum J, Poulsen $H E$. Buprenophine delays gastric emptying in man. Acta Anaesthesiol Scand 1985; 29: 599-601

11 Shimm DS, Longue GL, Maltbie AA, Dugen S. Medical management of chronic cancer pain. JAMA 1979; 241 : 2408-12.

12 Ingram DM, Sheiner HJ. Postoperative gastric emptying. Br J Surg 1981; 68: 572-6.

\section{Résumé}

Dans une étude à double insu, on a mesuré l'effet d'une dos" unique i.v. (25 mg) de chlorpromazine sur la vidange gastrique tel que déterminé par le taux d' absorption de paracétamol, chez sept volontaires en santé. Chaque volontaire étail son propre témoin. Les dekx fois, il n'y avait pas de différence significative dans la concentration ntaximale de paracétamol, le temps requis pour atteindre la concenration plasmatique maximale, et la surfoce sous la courbe du temps de la concentration plasmatique de 0-120 minutes, ae qui démontrait une vidange gastrique inaltérée après l'administration de chlorpromazine. 